\title{
Deranged $\alpha$-Adrenergic Regulation of Growth Hormone Secretion in Poorly Controlled Diabetes: Reversal of the Exaggerated Response to Clonidine after Continuous Subcutaneous Insulin Infusion
}

\author{
EYTHAN TOPPER, JOSEPH GERTNER, STEPHANIE AMIEL, MARTIN PRESS, MYRON GENEL, \\ AND WILLIAM V. TAMBORLANE \\ Department of Pediatrics and the Children's Clinical Research Center, Yale University School of Medicine, \\ New Haven, Connecticut 06510
}

\begin{abstract}
Elevated plasma growth hormone (GH) and peripheral catecholamine levels are frequently observed in poorly controlled, insulin-dependent diabetes. Since the alpha adrenergic system plays an important role in hypothalamic regulation of GH secretion, we tested the hypothesis that altered central adrenergic activity contributes to the increased GH concentrations in diabetes. Clonidine, an $\alpha$-adrenergic agonist, was administered to nine poorly controlled, young diabetic patients (age 12-19 yr) before and after 1 wk of continuous subcutaneous insulin infusion pump therapy. As expected, continuous subcutaneous insulin infusion lowered mean 24-h plasma glucose (from $203 \pm 21$ to $112 \pm 7 \mathrm{mg} / \mathrm{dl}, p<0.01$ ) and $\mathrm{GH}$ (from 17.7 \pm 2.1 to $9.2 \pm 1.2 \mathrm{ng} / \mathrm{ml}, p<0.01$ ) to values observed in normal controls. In the diabetic patients during conventional treatment, both the peak plasma GH level postclonidine $(48.3 \pm 8.7 \mathrm{ng} / \mathrm{ml})$ and the incremental area under the $\mathrm{GH}$ response curve $(3.23 \pm 0.58 \mathrm{mg} \cdot \mathrm{min} / \mathrm{ml})$ were significantly increased above normal control values $\mathbf{( 2 5 . 2}$ $\pm 2.1 \mathrm{ng} / \mathrm{ml}, p<0.05$ and $1.63 \pm 0.11 \mathrm{mg} \cdot \mathrm{min} / \mathrm{ml}, p<$ 0.0025 , respectively). In contrast, the $\mathrm{GH}$ response to clonidine was indistinguishable from normal after only 1 wk of intensified insulin treatment. Our findings support the contention that metabolic control of diabetes influences hypothalamic regulation of GH secretion and suggests that such alterations are related, at least in part, to changes in central $\alpha$-adrenergic activity. (Pediatr Res 19: 534-536, 1985)
\end{abstract}

\section{Abbreviations}

GH, growth hormone

CSII, continuous subcutaneous insulin infusion

Elevated plasma GH concentrations during 24-h monitoring (1) and following provocative stimuli (2-4) have been frequently observed in poorly controlled, insulin-dependent diabetic pa-

Received December 18, 1984; accepted January 30, 1985.

Address for correspondence and reprints: Eythan Topper, M.D., Department of Pediatrics, Yale University School of Medicine. 333 Cedar Street, New Haven, CT 06510

Supported by Grant RR-00125 to the Yale Children's Clinical Research Center from the National Institute of Health and a grant from the Juvenile Diabetes Foundation International. tients but the mechanism remains obscure. We have reported that the exaggerated plasma $\mathrm{GH}$ and catecholamine responses to exercise in diabetes are reduced to normal following improvements in glucose control with CSII (5). Since the $\alpha$-adrenergic system plays an important role in the hypothalamic regulation of $\mathrm{GH}$ secretion $(6,7)$, alterations in central adrenergic activity might provide a link between poorly controlled diabetes and hypersecretion of GH. This hypothesis was tested in the present study by determining the effect of the $\alpha$-adrenergic agonist, clonidine (8), on $\mathrm{GH}$ release before and after a short period (1 wk) of intensified insulin therapy.

\section{MATERIALS AND METHODS}

Diabetic patients. Nine nonobese patients with insulin-dependent diabetes, one male and eight females, were studied. The clinical data including total glycosylated $\mathrm{Hb}$ and plasma glucose levels at entry to the study are summarized in Table 1 . The patients ranged in age from 12-19 yr, and duration of diabetes from 2-10 yr. At entry to the study, the patients were conventionally treated with one to two daily injections of mixed medium and short acting insulins and insulin was the only medication being taken regularly. All diabetic and nondiabetic (see below) subjects and their parents gave informed written consent before taking part in the study. The study protocol was approved by the Human Investigation Committee of the Yale University School of Medicine.

Procedures. All the patients were admitted to the Yale Children's Clinical Research Center. The patients were initially studied while receiving their usual insulin and dietary treatment. On the morning of the second hospital day an indwelling catheter was inserted into a forearm vein and blood obtained hourly for measurement of plasma glucose and every $2 \mathrm{~h}$ for $\mathrm{GH}$ for $24 \mathrm{~h}$. On the next morning, following an overnight fast, an oral clonidine test (4 $\mu \mathrm{g} / \mathrm{kg}$ body weight) (8) was carried out. Blood was obtained for $\mathrm{GH}$ before and every $30-60 \mathrm{~min}$ after clonidine administration for $240 \mathrm{~min}$. After completion of the clonidine study, insulin therapy was given by CSII using a battery-powered syringe pump (model AS6C, Auto-Syringe, Inc., Hooksett, NH). The basal infusion rate and premeal doses were adjusted according to blood glucose levels monitored eight to 10 times per day. After 7-8 days of CSII and near normalization of blood glucose concentrations, the 24-h monitoring for glucose and $\mathrm{GH}$ and the oral clonidine test were repeated.

Nondiabetic controls. Six healthy volunteers aged 12-19 yr were monitored hourly for $24 \mathrm{~h}$ for plasma glucose and $\mathrm{GH}$ 
Table 1. The clinical and laboratory data of the diabetic patients at the start of the study

\begin{tabular}{|c|c|c|c|c|c|}
\hline Patient & $\begin{array}{l}\text { Age } \\
(\mathrm{yr})\end{array}$ & $\begin{array}{c}\text { Duration } \\
(\mathrm{yr})\end{array}$ & $\begin{array}{c}\text { Glycosylated } \\
\mathrm{Hb}^{*}(\%)\end{array}$ & $\begin{array}{c}\text { Mean } \\
\text { plasma } \\
\text { glucose } \dagger \\
(\mathrm{mg} / \mathrm{dl})\end{array}$ & $\begin{array}{c}\text { Insulin } \\
\text { dose (U/ } \\
\mathrm{kg} / \text { day) }\end{array}$ \\
\hline 1 & 19.2 & 12 & 15.6 & 158 & 1.91 \\
\hline 2 & 13.3 & 2 & 16.4 & 265 & 1.04 \\
\hline 3 & 16.7 & 5.7 & 14.4 & 213 & 1.09 \\
\hline 4 & 15.2 & 10 & 13.6 & 146 & 1.10 \\
\hline 5 & 17.7 & 2.5 & 13.9 & 296 & 0.54 \\
\hline 6 & 19.7 & 8 & 8.1 & 135 & 1.47 \\
\hline 7 & 18.0 & 10 & 14.2 & 154 & 1.01 \\
\hline 8 & 14.0 & 6 & 18.2 & 268 & 0.52 \\
\hline 9 & 15.7 & 10 & & 197 & 0.98 \\
\hline
\end{tabular}

* Normal range 5.5 to $8.0 \%$.

$\dagger$ Mean of hourly samples for $24 \mathrm{~h}$.
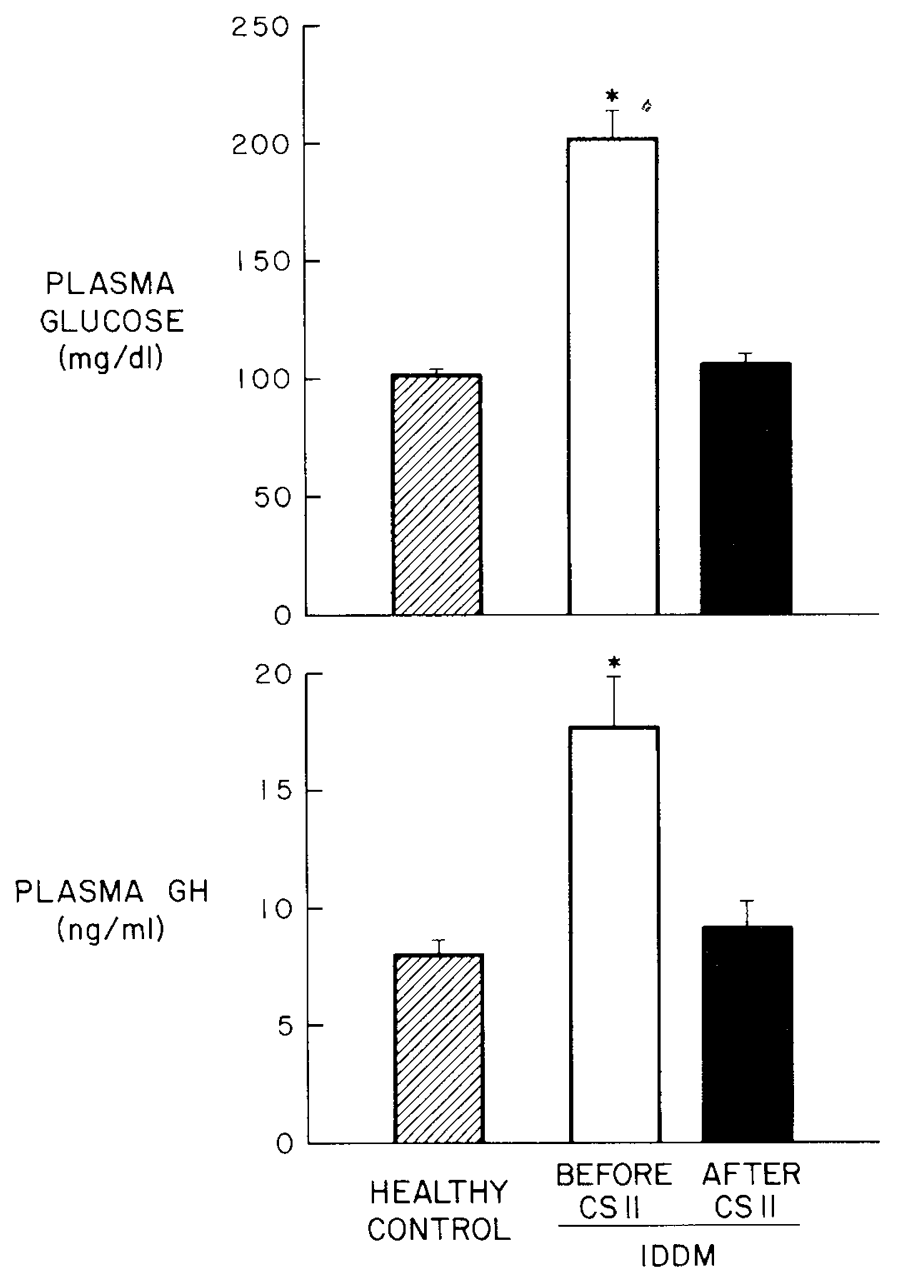

* $p<0.01$ vs CSII and Control

Fig. 1. Mean 24-h plasma glucose and $\mathrm{GH}$ in healthy controls (hatched bars) and in insulin-dependent diabetic subjects before (open bars) and after (closed bars) CSII.

profiles. Another 15 nondiabetic children aged 12-17 yr who had been evaluated for short stature and were found to have normal GH responses to exercise, L-dopa, and/or insulin-induced hypoglycemia served as the control group for the clonidine study. Each control subject was studied in the postabsorptive state and the oral dose of clonidine $(4 \mu \mathrm{g} / \mathrm{kg}$ body weight) and blood sampling procedures were the same as those used in the diabetic subjects.
Determinations and calculations. Plasma glucose levels were determined by a glucose analyzer (Beckman Instruments, Fullerton, $\mathrm{CA}$ ). Glycosylated $\mathrm{Hb}$ was measured microchromatographically using a commercial kit (Isolab Inc., Akron, OH). Plasma GH levels were quantitated by double-antibody radioimmunoassay using a standard provided by the National Hormone and Pituitary Agency. The data are presented as mean \pm SEM. The Student's $t$ tests (paired and unpaired) were employed in statistical analyses.

\section{RESULTS}

As shown in Figure 1, during conventional insulin treatment mean 24 -h plasma glucose $(203 \pm 21 \mathrm{mg} / \mathrm{dl})$ and $\mathrm{GH}(17.7 \pm$ $2.1 \mathrm{ng} / \mathrm{ml}$ ) levels were significantly elevated in the diabetics above normal control values $(102 \pm 2.1 \mathrm{mg} / \mathrm{dl}, p<0.01$ and $8.0 \pm 0.6$ $\mathrm{ng} / \mathrm{ml}, p<0.01$, respectively). In contrast, near normalization of plasma glucose with CSII was accompanied by a significant reduction in mean $24-\mathrm{h}$ plasma $\mathrm{GH}$ concentrations to values $(9.2 \pm 1.2 \mathrm{ng} / \mathrm{ml}, p<0.01$ versus conventional treatment) indistinguishable from those seen in normal controls $(8.0 \pm 0.6$ $\mathrm{ng} / \mathrm{ml}$ ). A substantial fall in mean 24 -h plasma glucose (from $135 \pm 11$ to $84 \pm 6 \mathrm{mg} / \mathrm{dl}$ ) and $\mathrm{GH}$ (from $12.5 \pm 3.5$ to $6.9 \pm$ $1.2 \mathrm{ng} / \mathrm{ml}$ ) was observed with CSII even in the patient with the best metabolic control on conventional treatment (patient 6 , Table 1).

Mean plasma $\mathrm{GH}$ levels before and after oral clonidine administration in the diabetic patients and normal controls are shown in Figure 2. Basal $(0 \mathrm{~min}) \mathrm{GH}$ values in the diabetic subjects before $(10.5 \pm 1.7 \mathrm{ng} / \mathrm{ml})$ and after $(9.4 \pm 2.2 \mathrm{ng} / \mathrm{ml})$ CSII were slightly, but not significantly, different from basal values in the normal controls $(5.9 \pm 2.0 \mathrm{ng} / \mathrm{ml})$. In contrast, the $\mathrm{GH}$ response to clonidine was exaggerated in the diabetic subjects during conventional treatment and was rapidly restored to normal after intensified therapy (Fig. 2 and Table 2). As shown in Table 2, the peak GH level and the area under the $\mathrm{GH}$ response curve

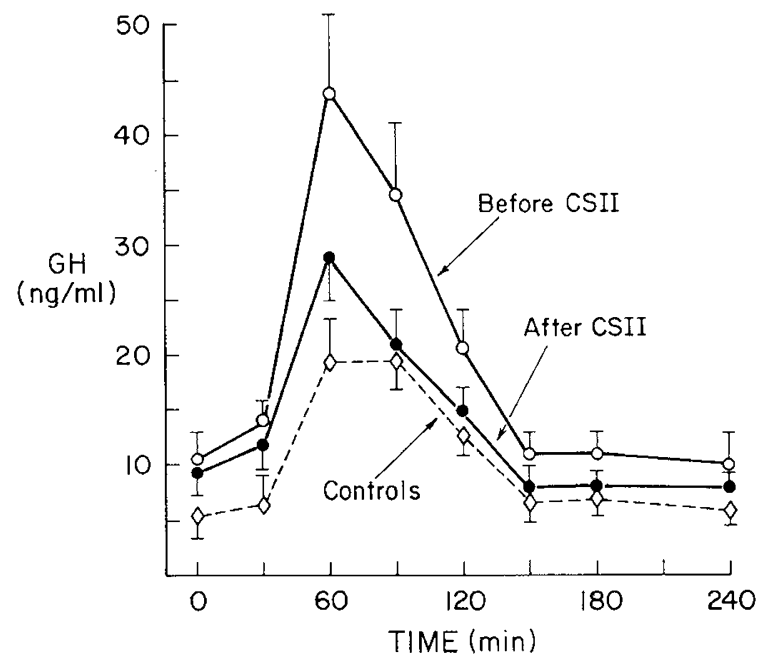

Fig. 2. Mean GH levels before and after clonidine administration in healthy controls $(\diamond)$ and in diabetics before $(O)$ and after $(\bullet)$ CSII.

Table 2. Effect of CSII on the GH response to clonidine

\begin{tabular}{llc}
\hline & $\begin{array}{c}\text { Peak Plasma } \\
\text { GH }(\mathrm{ng} / \mathrm{ml})\end{array}$ & $\begin{array}{c}\text { Area under GH response } \\
\text { curve }(\mathrm{mg} \cdot \mathrm{min} / \mathrm{ml})\end{array}$ \\
\hline Diabetics & & \\
Before CSII & $48.3 \pm 8.7^{*}$ & $3.23 \pm 0.58 \dagger$ \\
After CSII & $30.4 \pm 3.9$ & $1.95 \pm 0.33$ \\
Normal controls & $25.2 \pm 2.1$ & $1.63 \pm 0.11$ \\
\hline
\end{tabular}

* Significantly different from values in normal controls, $p<0.05$.

$\dagger$ Significantly different from values in normal controls, $p<0.0025$. 
were significantly increased above normal control values in our diabetic patients during conventional therapy. After only $1 \mathrm{wk}$ of CSII, on the other hand, both the peak GH level and the area under the curve were reduced to values similar to those in normal controls.

\section{DISCUSSION}

The increased plasma $\mathrm{GH}$ levels commonly observed in poorly controlled, insulin-dependent diabetes have been implicated in the pathogenesis of microangiopathy (9) and have recently been shown to contribute to the metabolic abnormalities of diabetes (10). As illustrated by our patients, treatment with CSII is capable of rapidly reducing mean 24-h GH levels to normal. Mean 24-h GH levels were reduced even in the patient (no. 6, Table 1) with apparently "good" diabetic control during conventional treatment. Similarly, intensified insulin treatment has been shown to reverse $\mathrm{GH}$ hypersecretion in response to exercise (3). The mechanisms underlying these changes in $\mathrm{GH}$ release have not been fully delineated.

There is little evidence to suggest that metabolic control of diabetes directly influences pituitary regulation of $\mathrm{GH}$ secretion. The pituitary response to stimulation by $\mathrm{GH}$ releasing factor is normal in hyperglycemic diabetics, albeit inappropriate for ambient plasma glucose concentrations (11). Furthermore, improved control with CSII, which lowers basal growth hormone levels, does not affect the pituitary response to GH releasing factor (12). On the other hand, hypersecretion of $\mathrm{GH}$ has been observed in conventionally treated diabetics in response to several stimuli such as arginine (4) and L-dopa (2) which are thought to act through the hypothalamus. However, deranged hypothalamic regulation of $\mathrm{GH}$ secretion in diabetes may be more selective than generally appreciated. For example, the $\mathrm{GH}$ response to hypoglycemia, the classical hypothalamic stimulus, is normal in poorly controlled diabetic patients and becomes subnormal with CSII (13).

In the present study, clonidine stimulation was used to probe the influence of diabetes control on hypothalamic, adrenergic regulation of $\mathrm{GH}$ secretion. Clonidine is an $\alpha$-adrenergic agonist which is known to act on presynaptic $\alpha-2$ receptors $(6,14)$. The $\mathrm{GH}$ response to clonidine has been reported to be useful in assessing changes in responsiveness of central-adrenergic receptors (15). We compared the GH response to clonidine in youngsters with diabetes to that in healthy non-GH deficient short children of comparable age. While it could be argued that such children do not constitute a "normal" population, the limitations of nontherapeutic research in children precluded use of a more conventional control group. In addition, the rise in $\mathrm{GH}$ postclonidine in our normal subjects was comparable to that reported by others (8) and each had shown a normal response to other provocative stimuli.

In our diabetic patients, the $\mathrm{GH}$ response to clonidine was markedly exaggerated during conventional insulin therapy. Even in the face of hyperglycemia, both the peak plasma GH level and the area under the plasma $\mathrm{GH}$ response curve following clonidine were increased by 2 -fold above values in nondiabetic controls. In contrast, only a brief period of intensified treatment was required to reduce clonidine-stimulated $\mathrm{GH}$ levels to normal control values. These findings support the hypothesis that metabolic control of diabetes influences hypothalamic regulation of GH secretion and suggests that these alterations are related to changes in responsiveness of central $\alpha$-adrenergic receptors or receptor activity. Whether the changes in adrenergic activity are modulated by other factors which may play a role in feedback control of $\mathrm{GH}$ secretion, such as insulin-like growth factor I (16, $17)$, remains to be investigated.

\section{REFERENCES}

1. Hayford JT, Danney MM, Hendrix JA, Thompson RG 1980 Integrated concentrations of growth hormone in juvenile-onset diabetes. Diabetes 29:391-398

2. Ailouni K, Martinson DR, Hagen T 1975 Effect of glucose on the growth hormone response to L-Dopa in normal and diabetic subjects. Diabetes 24:633-636

3. Hansen AP 1971 Normalization of growth hormone hyper-response to exercise in juvenile diabetes after "normalization" of blood sugar. J Clin Invest 50:1806-1811

4. Burday SZ, Fine PH, Schalch DS 1968 Growth hormone secretion response to arginine infusion in normal and diabetic subjects: relationship to blood glucose levels. J Lab Clin Med 71:897-901

5. Tamborlane WV, Sherwin RS, Koivisto V. Hendler R, Genel M, Felig P 1979 Normalization of the growth hormone and cathecholamine response to exercise in juvenile-onset diabetic subjects treated with a portable insulin infusion pump. Diabetes 28:785-788

6. Cella SG, Picotti GB, Muller EE $1983 \alpha_{2}$-Adrenergic stimulation enhances growth hormone secretion in the dog: a presynaptic mechanism: Life Sci 32:2785-2792

7. Martin JB 1978 Neural regulation of growth hormone secretion. Med Clin North Am 62:327-336

8. Gil-ad I, Topper E, Laron Z 1979 Oral clonidine as a growth hormone stimulation test. Lancet 1:278-280

9. Rabin D. Bloomgarden ZT. Feman SS, Davis TQ 1984 Development of diabetic complications despite the absence of growth hormone in a patient with postpancreatectomy diabetes. N Engl J Med 310:837-839

10. Press M, Tamborlane WV, Sherwin RS 1984 Importance of raised growth hormone levels in mediating the metabolic derangements of diabetes. $N$ Engl J Med 310:810-815

11. Press M. Tamborlane WV, Thorner MO, Vale W, Rivier J, Gertner J, Sherwin RS 1984 Pituitary response to growth hormone releasing factor in diabetes: failure of glucose-mediated suppression. Diabetes 33:804-806

12. Press M. Tamborlane WV. Thorner MO. Vale W, Rivier J, Gertner J. Sherwin RS 1984 Deranged regulation of GRF-stimulated growth hormone secretion in diabetes. Diabetes 33(suppl 1):13A(abstr)

13. Simonson D. Sherwin RS 1983 Insulin pump treatment reduces counterregulatory responses to hypoglycemia in Type 1 diabetes. Diabetes 32 (suppl 1) $36 \mathrm{~A}$ (abstr)

14. Svensson TH, Bunney BS, Agherjanian GK 1975 Inhibition of both noradrenergic and serotonergic neurons in brain by the alpha adrenergic agonist clonidine. Brain Res 92:291-306

15. Leckman J, Cohen D, Gertner J, Ort S, Harcherik D 1984 Growth hormone response to clonidine in children ages 4-17: Tourctte's syndrome vs. children with short stature. J Am Acad Child Psychiat 23:174-181

16. Topper E, Press M, Amiel S. Hintz. R, Genel M, Gertner J, Tamborlane WV 1984 Does a defect in insulin like growth factor-I $(\mathrm{IgFI})$ generation exist in insulin dependent diabetes (IDDM). Pediat Res 18:310A (abstr)

17. Tamborlane WV, Hintz RL, Bergman M. Genel M, Felig P, Sherwin RS 1981 Insulin infusion pump treatment of diabetes. Influence of improved metabolic control on plasma somatomedin levels. N Engl J Med 305:303-307 